\title{
Nutritional and Biochemical Properties of Fish Silage Prepared as an Ingredient in Poultry Feed
}

\author{
Rehana Raj $^{1 *}$, C.V. Raju ${ }^{2}$ I.P. Lakshmisha ${ }^{2}$ and Jagpal ${ }^{2}$ \\ ${ }^{1}$ Fish Processing Division, ICAR-CIFT, Matsyapuri, Cochin, Kerala, India \\ ${ }^{2}$ Department of Fish Processing Technology, College of Fisheries, \\ Mangaluru, Karnataka, India \\ *Corresponding author
}

\section{A B S T R A C T}

\begin{tabular}{|l|}
\hline K e y w o r d s \\
Nutritional and \\
Biochemical properties, \\
Poultry feed
\end{tabular}

Fish silage was prepared from fishery wastes collected from KFDC Karnataka. Fishery wastes was added with 1:1 ratio of $3 \%(\mathrm{v} / \mathrm{w})$ of formic acid and propionic acid and kept it for liquefaction. The $\mathrm{pH}$ was checked regularly which was maintained well below 4 and became stable. The proximate and quality parameters were analyzed periodically. The proximate parameters of the liquid silage was showing a moisture level of $81 \%$, protein of $15 \%$, fat of $5.78 \%$ and ash of $3.3 \%$. Among the quality parameters PV value ranged from $2.03 \pm 0.064$ to $2.14 \pm 0.062$ milliequivalent $/ \mathrm{kg}$, TBA value from $4.06 \pm 0.02$ to $4.25 \pm 0.06 \mathrm{mg}$ $\mathrm{N} / 100 \mathrm{~g}$, TMA value from $2.29 \pm 0.16 \mathrm{mg} \%$ to $3.72 \pm 0.13 \mathrm{mg} \%$, TVBN value from $19.01 \pm 0.12 \mathrm{mgN} / 100 \mathrm{~g}$ to $26.33 \pm 0.19 \mathrm{mgN} / 100 \mathrm{~g}$ and TPC value of $6.4 \times 10^{6} \mathrm{cfu} / \mathrm{g}$ initially and then showed a decreasing trend. The quality of silage remained prime during the storage period and hence can be included as a promising ingredient in the animal feed

\section{Introduction}

Generation of fishery wastes from fish processing plants is now causing alarming issues to environmental pollution. Transportation of these wastes to the area of safe disposal is not always a sustainable practice (Nunes, 1999). These generated wastes can be utilized in the manufacture of other byproducts there by reducing the pollution issues and also paving a way to revenue generation. Among the raw material volume received in the fish processing units the half is turning into wastes. But these wastes are rich source of low cost nutrients which can be well utilized (Oetterer, 2002).
The alternative is the utilization of these available wastes in generating by-products there by reduces the environmental pollution (Maia et al., 1998). The usually followed practice is the preparation of fish meal by using these generated wastes, which is not always a feasible activity. As this process is expensive, high energy consuming and requires highly qualified engineers and large amounts of fish waste. Hence the viable alternative is to produce fish silage out of these wastes which is highly cost effective and also acts as a source of supplement in making animal feed (Rahmi et al., 2008). It has been defined that fish silage is a liquid product produced from the whole fish or parts of it, to 
which acids, enzymes or lactic-acid-producing bacteria are added, with the liquefaction of the mass provoked by the action of enzymes from the fish (FAO, 2003). Preparation of fish silage involves the mixing of minced fish or parts of fish with acids or fermentable CHOs. Chemical silage is comparatively an easy technique which uses either organic acid or mineral acids. Organic acids are more expensive when compared to inorganic acids. Liquefaction process in organic acids can be carried out within a range of $\mathrm{pH}$ 3.5-4.5, which might be considered beneficial due to the anti-bacterial properties present in them. Also the use of organic acid such as formic acid and propionic acid in this $\mathrm{pH}$ range eliminates the need to neutralize the final product before it is incorporated as a feed ingredient. Strom et al., (1980) have demonstrated that propionic acid inhibit the fungus growth especially. Silage is a protein rich high biological value product for animal feeding, which involves dead fish, sub-utilized species, fishing by-products and industrial wastes.

These raw materials if not efficiently utilized may cause environmental, health and economic problems (Vidotti et al., 2003). During fish silage preparation the $\mathrm{pH}$ is lowered which liquefies the fish by the action of endogenously proteolytic enzymes. Reduction in $\mathrm{pH}$ also helps in the breakdown of bones and cartilage and also inhibits the growth of spoilage bacteria (Tatterson, 1982). Proteins are hydrolyzed during liquefaction and prolonged storage and yield soluble peptides, free aminoacids, $\mathrm{NH}_{3}$ and other metabolic products (Stone and Hardy, 1986). Fish silage has a high nutrient value and has essential amino acids in a balanced ratio where it can be used as promising protein supplement in livestock and aquaculture production (Strøm et al., 1979; Rungruangsak and Utne, 1981; Raa and Gildberg, 1982). In moist diets fish silage can be mixed directly or dried and mixed as an ingredient in animal feed. Co-dried silages with cereals are used in preparation of poultry feed (Disney et al., 1978). Fish silage is a best alternative to fish meal manufacturer since it can be applied even in small quantities or raw materials, thereby eliminating the need for heavy and expensive processing equipment and maintenance. There is a better chance to produce huge amount of fish silage in tropical countries due to the availability of byproduct from capture, industrial wastes and also bycatch fish (Durairaj et al., 1976; Gildberg and Raa, 1977). In fish farming and animal rearing $60 \%$ of the expenses are incurred in feed cost which can be easily reduced to by adding fish silage as a protein supplement in animal feed (Arruda, 2007).

\section{Materials and Methods}

Fish wastes were collected from KFDC, Mangaluru, Karnataka. Collected wastes were washed thoroughly in potable water. The wastes were then chopped well and were transferred to a plastic tank. A 1:1 ratio of 3\% (v/w) of formic acid and propionic acid was added to the chopped fishery wastes and mixed thoroughly. The initial $\mathrm{pH}$ was checked.

The mixture was left in the tank for liquefaction at room temperature and stirred well both in the morning and evening. $\mathrm{pH}$ changes was recorded daily. Proximate composition of silage which includes moisture, protein, fat and ash was done. Biochemical parameters such as TVBN, TMA, PV and TBA were performed according to AOAC (2005). AAN measured according to Benjakul and Morrissey (1997), T-VBN measured according to Beatty and Gibbons (1937) and TPC. To determine the quality of the prepared silage microbiological parameter such as TPC was carried out initially to check the acceptability of the product. 


\section{Results and Discussion}

\section{Determination of $\mathrm{pH}$ of the fish silage}

The $\mathrm{pH}$ of the silage was monitored daily. $5 \mathrm{gm}$ of the sample was taken and homogenized with $45 \mathrm{ml}$ of distilled water and checked with $\mathrm{pH}$ meter. It showed a regular trend without much fluctuation. The $\mathrm{pH}$ showed a slight variation and finally fixed to 4 at the end of day 21. There was not much variation in $\mathrm{pH}$ which leads to a complete liquefaction of the sample.

\section{Determination of proximate composition}

The proximate composition of the fish silage was analyzed and recorded. Proximate composition of the raw fish waste, liquid fish silage and dried fish silage was carried out. The proximate composition of the analyzed sample is given in table 1 .

\section{Determination of PV}

The oxidation of the fish silage was analyzed by analyzing the Peroxide Value (PV). The
PV was found to slow increase in values followed by constant values. The PV of the fish waste initially showed a value of $2.03 \pm 0.064 \mathrm{milliequivalent} / \mathrm{kg}$ of oil and the final fish silage demonstrated the value $2.14 \pm 0.062$ milliequivalent $/ \mathrm{kg}$ of oil by the end of 27 days. Babu et al., (2005) reported PV of 2.32 milliequivalent $/ \mathrm{kg}$ of oil for $3 \%$ formic acid and 4.68 milliequivalent $/ \mathrm{kg}$ of oil for $2.5 \%$ formic acid silages

\section{Determination of TBA}

The TBA of the sample was analyzed which gave an initial value of $4.06 \pm 0.02 \mathrm{mgN} / 100 \mathrm{~g}$ and which exhibited a value of $4.25 \pm 0.06$ $\mathrm{mgN} / 100$ by $14^{\text {th }}$ day and which remained stable throughout the period of hydrolysis.

The product of TMA is dependent on the bacterial activity as well as from endogenous enzymes (Mohd'Yusuf et al., 2010).

The recommended level of TMA value for human consumption is 10 to $15 \mathrm{mg} \mathrm{N} / 100 \mathrm{~g}$ (Connell, 1995).

\section{Determination of $\mathrm{pH}$ of the fish silage}

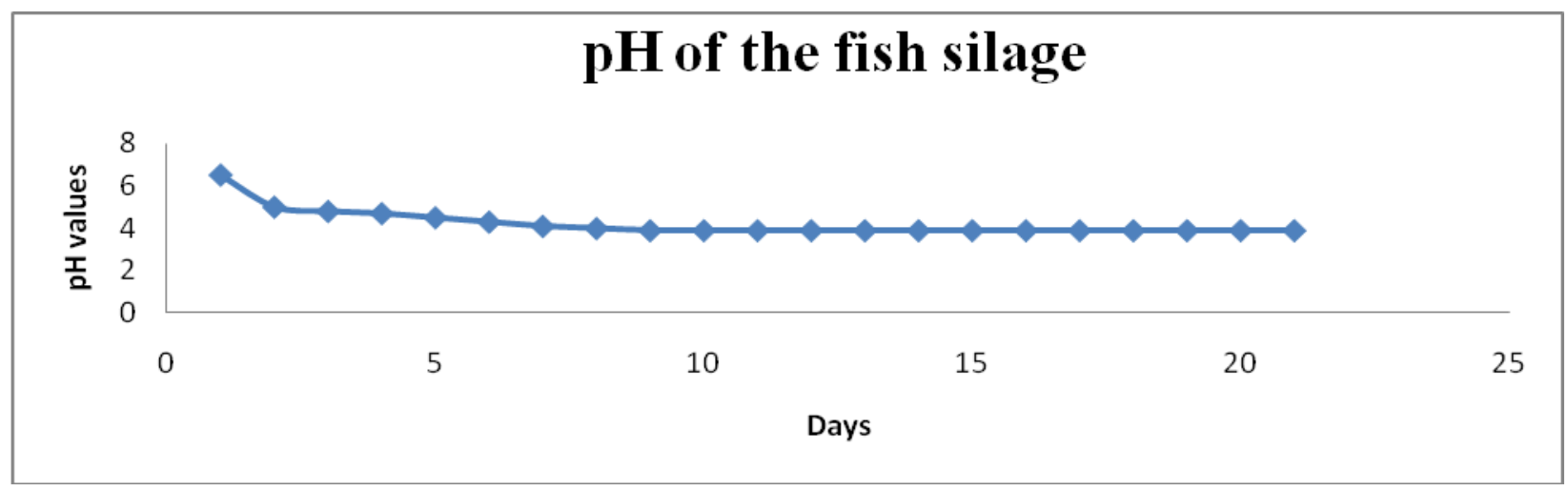

Table.1 Proximate composition of the samples analyzed

\begin{tabular}{|c|c|c|c|c|}
\hline Ingredients & Moisture & Protein & Fat & Ash \\
\hline Raw fish waste & 74.61 & 19.05 & 3.38 & 5.21 \\
\hline Liquid fish silage & 80.825 & 15.3 & 5.78 & 3.3 \\
\hline
\end{tabular}




\section{Determination of TMA}

The acceptable limit of TMA values ranged from $1.4 \mathrm{mg} \%$ to $9 \mathrm{mg} \%$. There was a constant reduction in the values of TMA which indicated the reduction in the spoilage bacterial counts. As there is reduction in $\mathrm{pH}$ it is difficult for the putrefying bacteria to survive which led to the reduction of TMA values. The TMA value for the initial lot was $2.29 \pm 0.16 \mathrm{mg} \%$ for the initial lot of the raw wastes and which gradually showed a slight increase to $3.72 \pm 0.13 \mathrm{mg} \%$ for the fish silage at the end of 28 days. As proteolysis increases, it may also lead to the increase in TMA levels.

\section{Determination of TVBN}

TVBN values represent the amount of volatile nitrogen compound released by the degradation of nitrogenous compounds on action with acid as well as enzymes present in the fishes. As nitrogenous compounds break down more and more liquefaction occurs. It has been reported that liquefaction of protein is more in acid silages than in fermented silages. The initial TVBN value of the fishery wastes was $19.01 \pm 0.12 \mathrm{mgN} / 100 \mathrm{~g}$ and it was finally increased upto $26.33 \pm 0.19 \mathrm{mgN} / 100 \mathrm{~g}$ until 28 days.

Almost similar values was obtained for the silage prepared from fishery wastes by Palkar et al., 2017which came to around $27.16 \mathrm{mgN} / 100 \mathrm{~g}$ for $2.5 \%$ formic acid and $25.25 \mathrm{mgN} / 100 \mathrm{~g}$ for $3.5 \%$ formic acid silages after 24 days. TVBN levels were well below acceptable limit for the silage with and without antioxidant even after 90 days (Tanuja et al., 2014). Tissues degrading enzymes, digestive enzymes or proteolytic enzymes present in the fish can be cause of release of high amount of nitrogenous compounds leading to the increase in TVBN values (Hammoumi et al., 1998).

\section{Determination of TPC}

TPC of the silage samples were analyzed to indicate the microbial load in silage. The initial TPC value of the pink perch waste was $6.4 \times 10^{6} \mathrm{cfu} / \mathrm{g}$ which finally showed a gradual reduction. Palekar (2009) $\left(5.1 \times 10^{6} \mathrm{cfu} / \mathrm{g}\right)$ and Palkar et al., 2017(6.7 $\left.\times 10^{6} \mathrm{cfu} / \mathrm{g}\right)$ has demonstrated similar results in the case of pink perch wastes and also in market fishery wastes.

Fish silage is a cheap and environment friendly alternative method for waste-fish utilization and prevents dumping in environment which leads to pollution in many coastal fishing communities. It is also a better and cheap alternative to be added in animal feed as a good protein supplement. In this study it was observed that the proximate and the biochemical composition of the silage remained acceptable throughout. Even though there was an increase in TVBN, TMA, TBA and $\mathrm{PV}$ values it was within the limit. $\mathrm{pH}$ of the reached stable within $7^{\text {th }}$ day and remained constant at 4. This $\mathrm{pH}$ value aided in liquefying the wastes and also controlled the growth of microorganisms. However, liquefaction due to the proteolytic enzymes may produce a good product which would contain available ingredients that could be used by the digestive system of the animal fed on the product. Hence silage in a highly beneficial product as a protein supplement in animal feed by replacing soybean at certain levels. It is very cheap and easy to prepare and is a beneficiary product for small scale backyard poultry farmers.

\section{References}

APHA, 1992 Compendium of methods of the microbiological examination of foods. M. L. Speck, (Ed). APHA, Publication, Washington, U.S.A. 
Arruda, L.F., Borghesi, R., and Oetterer, M. 2007. Use of Fish Waste as Silage - A review, Brazilian archives of biology and technology. Vol.50, 5: pp. 879-886.

Babu, J. U. S., Madhusudana Rao, B., Imam Khasim, D., and Nair, K. G. R. 2005. Biochemical and Microbial Quality of Formic Acid Silage and Lactobacillus Fermented Silage. Fish. Technol. Vol 42 (2) pp 163-170.

Beatty. S. A., and Gibbons, N.F. 1937. The Measurement of Spoilage in Fish. Journ. Biol. Bd., Canada, 3(1), 77-91.

Benjakul, S., and Morrissey, M.T. 1997. Protein hydrolysates from Pacific whiting solid wastes. Journal of Agricultural and Food Chemistry, 45, 3423-3430.

Connell, J.J. 1995. Control of fish quality. Fourth edition. Church Hill Livingstone Edinburg, Scotland. p. 245

Disney, J.G., Hoffman, A., Olley, J., Clucas, I.J., Barranco, A., and Francis, B.J.1978. Development of fish silage/carbohydrate animal feed for use in tropics. Trop. Sci. 20 (2): 29-143

Durairaj, S., Santhana Raj, T., Md. Sultan. K.M., and Dorai Rajah, K.A.P.A. 1976. In. Proc. Symp. Fish Processing Industry in India, Mysore, India

Faid, M., A., Zouiten, A., EL Marrakchi., and A. Achkari-Begdouri, 1997, Biotransformation of fish waste into a stable feed ingredient. Food Chemistry, Vol. 60, No. I, pp. 13-18

FAO. 2003, animal feed resources information system. http://www.fao.org. (23 Jan. 2003).

Gildberg, A., and J. Raa. 1977. Properties of a propionic acid/formic acid preserved silage of cod viscera. J. Sci. Food Agric. 28:647-653.

Gullu, K., and Guzel, S. 2003. A research on use in pellet of pearl mullet (Chalcalburnus tarichi) silage. Ekoloji. 12(48): 19-23.
Hammoumi, A., Faid, M., El Yachioui, M., and Amarouch, H. 1998. Characterization of fermented fish waste used in feeding trials with broilers. Process Biochemistry, 33(4), 423-427

Maia, W. M., Nunes, M.L., Figueiredo, M.J., and Bragagnolo. 1998. Caracterização da fraçãolipídica de silagem de resíduos de tilápia para utilizaçãoemrações para aaqüicultura. In: SimpósioBrasileiro de Aquicultura, 10, Anais. Recife: Persona, 2, 55-64.

Md Yusuf Ali, M.D., Iqbal, S., Ripon, K.A., and Omar, F. 2010. Post mortem variation in total volatile base nitrogen and trimethylamine nitrogen between Galda (Macrobrachium rosenbergii) and Bagda. (Penaeus monodon), Rajshahi University, Univ. J. Zool. 28:7-10

Nunes, M.L. (1999), Silagem de pescado. In: Ogawa, M.; Maia, E.L. Manual de pesca. SãPaulo: Livraria Varela, 1999. Pp.371-379.

Oetterer, M. (2002), Industrialização do pescadocultivado. Guaíba: Agropecuária, 200p.

Palekar, (2009) Transformation of fish waste into silage using Lactic Acid Bacteria. Submitted to B.S.K.K.V. Dapoli, Pp. 1115.

Palkar, N.D., Koli, J.M., Patange, S.B., Sharangdhar, S.T., Sadavarte, R.K., and Sonavane, A.E. 2017. Comparative Study of Fish Silage Prepared from Fish Market Waste by Using Different Techniques. Int.J.Curr.Microbiol. App.Sci., 6(12): 3844-3858

Raa, J. 1981. Biochemistry of microbial fish spoilage and preservation by lactic acid bacteria and added acid, p. 3-16. In S. 0. Emjuawie, Ogunbi, and S. Sanni (ed.), GIAM VI, Global impacts of applied microbiology. Academic Press, Inc., New York. 
Raa, J., and Gildberg, A. 1982. Fish silage; A Review. Crit. Rev. Series Food Sci. Nutr. 16: 383-419.

Raa, J., Gildberg, A., and Strom, T. 1983. Silage production-theory and practice. In upgrading aste for feeds and food. D.A. Ledward, A.J. Taylor and R.A. Lawria (Eds). Butterworths, London. pp. 117-132

Rahmi, M., MdFaid, MdElYachioui, El Hassan Berny, Md Fakir, and MdOuhssine. 2008. Protein rich ingredients from fish waste for sheep feeding African Journal of Microbiology Research Vol. (2) pp.073077

Rungruangsak, K., and F. Utne. 1981. Effect of different acidified wet feeds on protease activities in the digestive tract and on growth rate of rainbow trout (Salmo gairdneri Richardson). Aquaculture 22:67-79.

Stone, F.E. and Hardy, R.W. 1986. Nutritional value of acid stabilized silage and liquefied fish protein. J. Sci. Food Agri. 37: 797-803.

Storm, T., Gildberg, A., Stormo, B., and Raa, J. 1980. Fish silage, why not use propionic acid and formic acid? In. Connell, J.J., editor. Advances in fish science and technology. Oxford: Fishing New Books, pp. 352-355.

Strom, A. R., and H. Larsen. 1979. Anaerobic fish spoilage by bacteria. I. Biochemical changes in herring extracts. J. Appl. Bacteriol. 46:531-543.

Strom, T., and Eggum, B. 0. 1981. Nutritional value of fish viscera silage. J. Sci. Food Agric. 32:115-120.

Tanuja, S., Mohanty, P. K., Kumar, A., Moharana, A. and Nayak, S. K. 2014. Shelf life study of acid added silage produced from fresh water fish dressing waste with and without the addition of antioxidants. International Journal of Agriculture and Food Science Technology, 5(2): 91-98.

Tatterson, I.N. 1982. Fish silage preparation, properties and uses. Animal Feed Sci Technol. 7: 153-159

Turker A., and Buyukhatipoglu, S. 2006. The effect on performance and feed coast use of trout and bonito monger or anchovy in feeding of rainbow trout. J. Fact. Agric. OMU, 21(2): 167-172.

Vidotti, R.M., Viegas, E.M.M., and Carneiro, D.J. 2003. Amino acid composition of processed fish silage using different raw materials. Animal Feed Science and Technology 105: 199-204

Yildirim, O., Celikkale, M.S., Korkut, A.Y., and Hossu, B. 1999. Possibility of feeding rainbow trout (Oncorhynchusmykiss W., 1792) with fish longer by-products as an alternative feed source. Ege Uni. J. Fisheries and Aquatic Sci. 16(1): 159-174.

\section{How to cite this article:}

Rehana Raj, C.V. Raju, I.P. Lakshmisha and Jagpal. 2018. Nutritional and Biochemical Properties of Fish Silage Prepared as an Ingredient in Poultry Feed. Int.J.Curr.Microbiol.App.Sci. 7(05): 423-428. doi: https://doi.org/10.20546/ijcmas.2018.705.054 